\title{
IBM KELOMPOK TANI PADI RAKYAT (PENERAPAN VARIETAS UNGGUL HIBRIDA BARU DAN TEKNIK JAJAR LEGOWO)
}

\author{
Oleh : M. Zayin Sukri1) dan Titien Suhermiatien²) \\ 1) dan 2) Staf pengajar Jurusan Produksi Pertanian
}

\begin{abstract}
ABSTRAK
Peningkatan produktivitas padi masih cukup terbuka, karena adanya inovasi teknologi pertanian seperti: a) padi varietas unggul (tipe baru = VUTB; non Hibrida = VUB; Hibrida = VUH) yang mempunyai produktivitas tinggi, dan b) sistem tanam jajar legowo.

Sistem jajar legowo adalah teknik tanam yang mengatur jarak tanam antar rumpun dan antar barisan, sehingga terjadi pemadatan rumpun padi dalam barisan serta jarak antar barisan juga lebih lebar. Jumlah rumpun tanaman padi yang ditanam dengan sistem budidaya legowo 2:1 jarak tanam $40 \mathrm{~cm} \mathrm{x}$ $20 \mathrm{~cm}$ x $10 \mathrm{~cm}$ mencapai 333.333 rumpun/ha, sedangkan pada sistem tegel jarak tanam $20 \mathrm{~cm}$ x $20 \mathrm{~cm}$ adalah 250.000 rumpun/ha. Jumlah rumpun tiap hektar sistem budidaya legowo 33,3\% lebih banyak dibanding sistem tegel.

Keuntungan teknik tanam jajar legowo dua barisan adalah: a) semua barisan pada bagian pinggir memberikan hasil lebih tinggi 1,5 - 2 kali lipat dari produksi yang berada di barisan dalam, b) pengendalian hama, penyakit dan gulma lebih mudah, c) terdapat ruang kosong untuk saluran pengaturan air, pengumpul keong mas serta mina padi, d) aplikasi pupuk lebih efektif. Berdasarkan kondisi di atas maka program IbM kombinasi penerapan varietas unggul hibrida baru dengan produktivitas tinggi dan teknik jajar legowo diharapkan mampu meningkatkan produktivitas padi di tingkat petani.

Dari kegiatan IbM Kelompok tani padi rakyat, dengan penerapan varietas unggul hibrida baru dan teknik jajar legowo yang telah dilaksanakan dapat disimpulkan sebagi berikut: 1) Budidaya tanaman dengan varietas unggul hibrida baru dan teknik jajar legowo dapat berjalan dengan sebagaimana yang direncanakan; 2) Pertumbuhan tanaman padi hibrida dengan hibrida tampak lebih subur dan lebih produktif dibanding padi non hibrida; 3)Pertumbuhan tanaman pada baris bagian tepi sistem jajar legowo lebih baik dari tanaman pada sistem tanam biasa; 4) Peningkatan hasil gabah varietas hibrida dibanding non hibrida adalah 20,42\%, peningkatan hasil sistem legowo 2:1 dibanding sistem tegel 20x20 adalah 9,29\%, peningkatan hasil sistem legowo 5:1 dibanding sistem tegel $20 x 20$ adalah 6,24\%.
\end{abstract}

Keyword : Hibrida, jajar legowo, varietas unggul.

\section{PENDAHULUAN}

\section{Analisis Situasi}

Peluang peningkatan produktivitas padi masih cukup terbuka, karena adanya inovasi teknologi pertanian seperti: (a) padi varietas unggul (tipe baru = VUTB; non Hibrida = VUB; Hibrida $=$ VUH) yang mempunyai produktivitas tinggi, (b) system tanam jajar legowo, dan (c) inovasi teknologi usahatani seperti PengelolaanTanaman Terpadu (PTT), system rice of intensification (SRI), sistem integrasi padi-ternak (SIPT).

Beberapa penelitian penerapan padi varietas unggul antara lain dilakukan oleh Sumiyati (2007) menggunakan galur IPB 97-131 yang potensi hasil panen 8,4 ton GKG/ha. Sembiring (2008) membagi padi VUB menjadi 6 kelas yaitu: (a) varietas unggul produktivitas tinggi, (b) Varietas unggul hasil stabil, (c)
Varietas unggul cita rasa, (d) Varietas unggul mutu gizi, (e) Varietas unggul mutu gizi, (f) Varietas unggul sawah dataran tinggi, serta (g) Varietas unggul genjah.

Padi varietas hibrida yang telah diperkenalkan hingga sekarang terdapat 31 varietas unggul hibrida (VUH), enam varietas yaitu Maro, Rokan, Hipa 3, Hipa 4, Hipa 5-Ceva, dan Hipa 6-Jete. Padi hibrida merupakan turunan pertama (F1) hasil persilangan 2 induk berbeda, superioritasnya hanya muncul pada F1. Padi hibrida cocok dibudidayakan lahan subur dan intensif.

Padi tipe baru merupakan padi yang mempunyai arsitektur/tipe baru dengan sifat batang kuat, anakan sedang (9-12) tetapi produktif semua, malai panjang dengan 200-300 butir gabah/malai, persentase gabah isi tinggi (90\%), umur genjah (110-120 hari), sistem perakaran dalam dan banyak, tinggi tanaman 
sedang-pendek (100-110 cm) serta daun tegak, tebal, dan berwarna hijau tua (Abdullah et al., 2004).

Sistem jajar legowo adalah teknik tanam yang mengatur jarak tanam antar rumpun dan antar barisan, sehingga terjadi pemadatan rumpun padi dalam barisan serta jarak antar barisan juga lebih lebar. Komponen penentu hasil padi adalah jumlah malai persatuan luas (Prajitno et al., 2006). Jumlah rumpun tanaman padi yang ditanam dengan sistem budi daya legowo 2:1 jarak tanam $50 \mathrm{~cm}$ x $25 \mathrm{~cm} \times 15 \mathrm{~cm}$ mencapai 178.000 rumpun/ha, sedangkan pada sistem tegel jarak tanam $25 \mathrm{~cm}$ x $25 \mathrm{~cm}$ adalah 160.000 rumpun/ha. Jumlah rumpun tiap hektar sistem budi daya legowo 11,25\% lebih banyak dibanding sistem tegel.

Menurut Permana (1993), keuntungan teknik tanam jajar legowo dua barisan adalah: (a) semua barisan pada bagian pinggir memberikan hasil lebih tinggi 1,5 - 2 kali lipat dari produksi yang berada di barisan dalam, (b) pengendalian hama, penyakit dan gulma lebih mudah, (c) terdapat ruang kosong untuk saluran pengaturan air, pengimpul keong mas serta mina padi, (d) aplikasi pupuk lebih efektif (Suhendrata et al., 2004; Badan Litbang Pertanian, 2007; Suhendrata et al., 2008). Hasil system tanam jajar legowo dua baris dengan jarak tanam $20 \times 10 \times \quad$ x $40 \quad \mathrm{~cm}$ mampu meningkatkan produksi hingga 560 - 1.550 $\mathrm{kg} / \mathrm{ha}$ dibanding dengan system tegel dengan jarak tanam $20 \times 20 \mathrm{~cm}$. Keuntungan yang diperoleh meningkat dari 1,16 menjadi 1,43 dengan peningkatan keuntungan Rp. 1.352.000,/ha (Widarto dan Yulianto, 2001).

Berdasarkan kondisi di atas maka program IbM kombinasi penerapan varietas unggul hibrida baru dengan produktivitas tinggi dan teknik jajar legowo diharapkan mampu meningkatkan produktivitas padi di tingkat petani.

\section{Permasalahan Mitra}

Kondisi petani mitra umumnya membudidayakan padi varietas IR-64. Hal ini dikarenakan sudah dilakukan secara turun temurun, sehingga tidak ada keberanian untuk beralih ke varietas lain. Hasil wawancara dengan petani mitra IbM, terdapat beberapa permasalahan peningkatan produktivitas padi di tingkat petani, yaitu:

1. Kurangnya sosialisasi varietas dan system tanam baru sehingga banyak petani yang tidak mengetahuinya.
2. Keterbatasan benih padi varietas unggul baru, baik dalam jumlah, mutu maupun jenis varietasnya.

3. Adanya kesenjangan mutu benih yang beredar dengan preferensi petani meliputi: produktivitas tinggi, rasa enak, umur genjah, punel, tinggi tanaman sedang, ketahanan terhadap hama dan penyakit dan lain-lain.

\section{Justifikasi dalam menentukan persoalan prioritas yang akan diselesaikan}

Keberhasilan program tergantung komitmen atau kesepakatan antara pelaksana IbM dengan masyarakat kelompok petani mitra IbM. Kesepakatan tersebut antara lain:

1. Pihak Pengusul IbM

a) Pengusul IbM mengenalkan varietas baru dan teknik tanam jajar legowo untuk meningkatkan produktivitas hasil panen padi.

b) Pengusul IbM membiayai pelaksanaan kegiatan budidaya dengan varietas unggul baru dan teknik tanam jajar legowo melalui program IbM.

c) Pengusul IbM menyediakan sarana dan prasarana budidaya padi tersebut.

d) Hasil panen budidaya varietas baru system jajar legowo menjadi modal awal bagi kelompok tani untuk mengembangkan system jajar logowo.

2. Pihak Kelompok Tani Siboga dan Kelompok

Tani Gempal 2.

a) Kelompok tani menyediakan lahan masing-masing seluas 0,5 ha untuk pelaksanaan budidaya padi vaerietas baru dengan teknik tanam jajar legowo. Lahan tersebut disewa melalui program IbM.

b) Kelompok tani berkwajiban melakukan budidaya varietas unggul baru dan teknik tanam jajar legowo mulai dari persiapan hingga panen.

c) Kelompok tani memberikan data-data pendukung kepada pelaksana IbM sehingga bisa dilakukan analisis finansial dari budidaya baru dengan budidaya konvensional yang umum dilakukan petani.

d) Kelompok menyebarluaskan system jajar legowo dengan menggunakan varietas baru kepada anggota kelompok.

\section{TARGET DAN LUARAN}

Target dari kegiatan IbM ini adalah:

1. Masing-masing kelompok tani IbM melakukan budidaya padi dengan varietas baru system jajar legowo masing-masing 
seluas 0,5 ha sehingga diperoleh total panen berkisar 10 ton.

2. Kelompok tani mitra mempunyai pengetahuan, ketrampilan dan kesadaran tentang manfaat budidaya padi varietas baru system jajar legowo.

3. Minimal terdapat 10 anggota kelompok tani menerapkan sistem tanam jajar legowo pada masing-masing kelompok tani, setelah program IbM selesai dengan tetap dipantau dan diawasi oleh pengusul program IbM dan Penyuluh Pertanian terkait.

Luaran dari kegiatan IbM ini adalah:

1. Budidaya padi varietas baru meningkatkan produktivitas 1,0 sampai 2,4 ton/ha bila dibandingkan dengan varietas IR-64.

2. Budidaya padi system jajar legowo dua baris dengan jarak tanam $20 \times 10 \times 40 \mathrm{~cm}$ mampu meningkatkan produksi hingga 560-1.550 $\mathrm{kg} / \mathrm{ha}$ dibanding dengan system tegel dengan jarak tanam 20 × $20 \mathrm{~cm}$.

3. Bila keduanya dikombinasikan maka akan mampu meningkatkan produktivitas yang lebih tinggi sehingga pendapatan petani yang tergabung dalam kelompok tani lebih besar lagi.

4. Analisis finansial budidaya kombinasi varietas unggul hibrida baru dengan system jajar legowo dibandingkan dengan budidaya konvensional yang dilakukan petani saat ini.

5. Jurnal ilmiah analisis finansial budidaya padi kombinasi varietas baru system jajar legowo.

\section{METODE PELAKSANAAN}

Metode pelaksanaan kegiatan IbM ini adalah sebagai berikut:

1. Pengadaan Alat dan Saprodi, terdiri a) Alat Peraga dan ATK, b) Perlengkapan peserta, c) Benih varietas unggul hibrida baru, pupuk dan sarana produksi lainnya.

2. Kegiatan Pelatihan

a. Kegiatan pelatihan dilakukan baik di lapang maupun di kelas (Politeknik Negeri Jember) selama 4 kali pertemuan.

b. Instruktur dalam pelatihan budidaya jajar legowo berasal dari Politeknik Negeri Jember (Pelaksana IbM, dan Petugas Lapangan yang telah berpengalaman melaksanakan system jajar legowo).

c. Peserta merupakan anggota kelompok tani yang berminat melaksanakan jajar legowo didasarkan hasil penjaringan lokasi dan petani.

d. Materi yang disampaikan berupa teori dan praktek yang terdiri dari :
- Pengenalan Padi Varietas Unggil Hibrida Baru

- Cara Tanam Sistem jajar Legowo

- Pengamatan di lapangan

1. Pelaksanaan Demonstrasi Plot di lahan petani, adalah sebagai berikut :

a) Pembuatan pesemaian, diawali dengan pengolahan tanah yang dilakukan kurang lebih 21 hari sebelum tanam. Tanah diairi, dibajak, dicangkul dan diinjak-injak sehingga menjadi lumpur kemudian diratakan, bedengan dibuat dengan ukuran 1 x $10 \mathrm{~m}$ dan tinggi $0,2 \mathrm{~m}$. Luas persemaian $250 \mathrm{~m} 2$ untuk tanaman seluar 0,5 ha. Benih yang digunakan varietas unggul hibrida $40 \mathrm{~kg} / \mathrm{ha}$. Sebelumnya direndam air selama 24 jam dan diperam selama 24 jam.

b) Pengolahan lahan sawah, sebelum tanah diolah dilakukan penggenangan selama 1 hari. Pengolahan tanah pertama dilakukan dengan cara tanah dibajak yaitu tanah dibalik sambil jarami ditebarkan pada permukaan lahan, kemudian tanah dibiarkan. Pengolahan tanah kedua dilakukan satu minggu kemudian dengan cara menghancurkan bongkahan tanah dengan garu dan cangkul kemudian diratakan.

c) Pemupukan dasar, dilakukan dengan menggunakan pupuk SP36 sebanyak 100 $\mathrm{kg} / \mathrm{ha}$ dan $\mathrm{KCl}$ sebanyak $100 \mathrm{~kg} / \mathrm{ha}$, dilakukan 1 hari sebelum tanam.

d) Penanaman, dilakukan pada saat bibit berumur 21 hari sebanyak 2 bibit per lubang tanam, dengan sistem tanam jajar legowo 2:1 dan 5:1. Jajar legowo 2:1 yaitu jarak dalam baris $10 \mathrm{~cm}$, jarak antar baris $20 \mathrm{~cm}$, kemudian jarak antar 2 baris yang satu dengan 2 baris yang lainnya $40 \mathrm{~cm}$. Sedangkan jajar legowo 5:1 yaitu jarak antar baris $20 \times 20 \mathrm{~cm}$ berjajar 5 baris dan pada baris bagian pinggir jarak dalam baris baris dirapatkan menjadi $10 \mathrm{~cm}$. Jarak baris pada pinggir yang satu dengan baris pinggir lainnya $40 \mathrm{~cm}$ (Gambar 1).

e) Pemupukan susulan pertama, dilakukan pada umur 3 minggu setelah tanam dengan menggunakan pupuk Urea dengan dosis 100/ha, pemupukan susulan berikutnya 6 minggu setelah tanam dengan menggunakan campuran pupuk Urea dan Ponska masing-masing $100 \mathrm{~kg} / \mathrm{ha}$.

f) Penyiangan, dilakukan 2 kali yaitu pada umur 3 dan 6 minggu setelah tanam 
dengan cara mencabut rumput dan membenamkannya ke dalam tanah.

g) Pengendalian hama dan penyakit, dilakukan apabila terdapat gejala serangan hama/penyakit dengan menggunakan insektisida/ fungisida yang dianjurkan. Pengendalian manual dilakukan untuk mengendalikan keong mas.

h) Pengairan disesuaikan dengan keadaan pertumbuhan tanaman, dengan cara menggenangi lahan pertanaman selama pertumbuhan sampai satu minggu menjelang panen.

i) Panen, dilakukan pada saat tanaman masak fisiologis yaitu 90\% malai tampak menguning.

j) Perontokan dilakukan bersamaan atau sesaat setelah panen selesai dengan menggunakan mesin perontok padi.

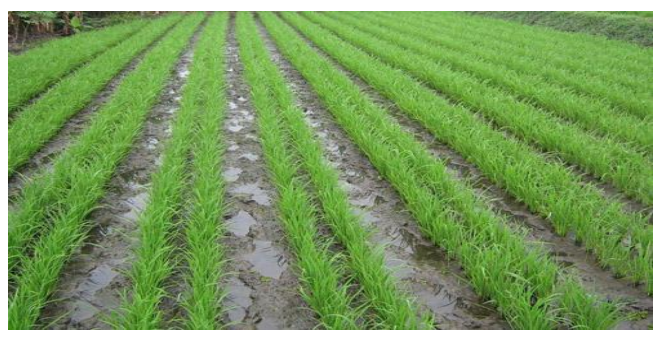

Jajar legowo 2:1



Jajar legowo 5:1

\section{HASIL DAN PEMBAHASAN}

Hasil yang dicapai dari kegiatan IbM Kelompok tani padi rakyat, penerapan varietas unggul hibrida baru dan teknik jajar legowo, meliputi:

1. Pembuatan pesemaian, diawali dengan pengolahan tanah yang dilakukan kurang lebih 21 hari sebelum tanam. Tanah diairi, dibajak, dicangkul dan diinjak-injak sehingga menjadi lumpur kemudian diratakan, bedengan dibuat dengan ukuran $1,25 \times 10 \mathrm{~m}$ dan tinggi $0,2 \mathrm{~m}$, sebanyak 10 bedeng. Benih yang digunakan benih hibrida varietas DG 1 (Sang Hyang Seri) sebanyak $40 \mathrm{~kg} / \mathrm{ha}$ atau $50 \mathrm{gr} /$ bedeng. Sebelum disebar benih direndam air selama 24 jam dan diperam selama 24 jam.

2. Pengolahan lahan sawah, sebelum tanah diolah dilakukan penggenangan selama 2 hari. Pengolahan tanah pertama dilakukan dengan cara tanah dibajak dengan handtraktor yaitu tanah dibalik, kemudian dihancurkan dan diratakan.

3. Pemupukan dasar, dilakukan dengan menggunakan pupuk Urea sebanyak 100 $\mathrm{kg} / \mathrm{ha}$, TSP $100 \mathrm{~kg} / \mathrm{ha}$ dan KCl $100 \mathrm{~kg} / \mathrm{ha}$, dilakukan 1 hari sebelum tanam.

4. Penanaman, dilakukan pada saat bibit berumur 21 hari sebanyak 2 bibit per lubang tanam, dengan sistem tanam jajar legowo 2 : 1 , yaitu jarak dalam baris $10 \mathrm{~cm}$, jarak antar baris $20 \mathrm{~cm}$, kemudian jarak antar 2 baris yang satu dengan 2 baris yang lainnya $40 \mathrm{~cm}$. Di samping itu juga sistem legowo 5:1 di mana jarak jarak antar baris $20 \mathrm{~cm}$, tetapi jarak dalam baris yang paling pinggir $10 \mathrm{~cm}$, kemudian jarak antar 5 baris $40 \mathrm{~cm}$.

5. Pemupukan susulan dilakukan 2 kali, pertama pada umur 3 minggu setelah tanam dengan menggunakan pupuk ZA dan Ponska masing-masing $100 \mathrm{~kg} / \mathrm{ha}$ dan susulan kedua dilakukan umur 6 minggu setelah tanam menggunakan pupuk Urea dengan dosis $100 \mathrm{~kg} / \mathrm{ha}$.

6. Penyiangan, dilakukan 2 kali yaitu pertama pada umur 3 dan kedua akan dilakukan lagi pada umur 6 minggu setelah tanam dengan cara mencabut rumput dan membenamkannya ke dalam tanah.

7. Pengairan, dengan cara menggenangi lahan pertanaman selama pertumbuhan sampai satu minggu menjelang panen.

8. Pengendalian hama dan penyakit, dilakukan pada saat tanaman berumur 3 minggu setelah tanam dan diulang apabila terdapat gejala serangan hama/penyakit dengan menggunakan insektisida organik.

9. Penyemprotan pupuk organik cair (POC) dilakukan mulai tanaman berumur 2 minggu setelah tanam dan diulang setiap 2 minggu sekali.

10. Panen, dilakukan pada saat tanaman masak fisiologis yaitu $85 \%$ malai tampak menguning.

11. Perontokan dilakukan bersamaan atau sesaat setelah panen selesai dengan menggunakan mesin perontok padi (Thresser)

12. Hasil panen gabah kering panen dapat dilihat pada Tabel 1. 
Tabel 1. Perbandingan system tanam terhadap hasil padi varietas hibrida dan Ciherang

\begin{tabular}{|c|c|c|c|}
\hline \multirow[b]{2}{*}{ Sistem Tanam } & \multicolumn{2}{|c|}{$\begin{array}{l}\text { Hasil gabah per ha } \\
\text { (ton) }\end{array}$} & \multirow{2}{*}{$\begin{array}{c}\text { Peningkatan } \\
\text { hasil Hibrida } \\
\text { dibanding } \\
\text { non hibrida } \\
(\%)\end{array}$} \\
\hline & Ciherang & $\begin{array}{c}\text { Hibrida } \\
\text { DG1 }\end{array}$ & \\
\hline Tegel 20x20 & 6,10 & 7,46 & 22,30 \\
\hline Legowo 2:1 & 6,75 & 8,05 & 19,26 \\
\hline \multirow[t]{2}{*}{ Legowo 5:1 } & 6,55 & 7,84 & 19,69 \\
\hline & & \multicolumn{2}{|r|}{ Rata2 $=20,42$} \\
\hline \multirow{2}{*}{$\begin{array}{l}\text { Peningkatan hasil } \\
\text { Legowo } 2: 1 \\
\text { dibanding tegel } \\
20 \times 20(\%)\end{array}$} & 10,66 & 7,91 & \\
\hline & \multicolumn{2}{|c|}{ Rata $2=9,29$} & \\
\hline \multirow{2}{*}{$\begin{array}{l}\text { Peningkatan hasil } \\
\text { Legowo 5:1 } \\
\text { dibanding tegel } \\
20 \times 20(\%) \\
\end{array}$} & 7,38 & 5,09 & \\
\hline & \multicolumn{2}{|c|}{ Rata $2=6,24$} & \\
\hline \multirow{2}{*}{$\begin{array}{l}\text { Peningkatan hasil } \\
\text { Legowo 2:1 } \\
\text { dibanding } \\
\text { Legowo 5:1 (\%) }\end{array}$} & 3,05 & 2,68 & \\
\hline & \multicolumn{2}{|c|}{ Rata $2=2,87$} & \\
\hline
\end{tabular}

\section{KESIMPULAN DAN SARAN}

Dari kegiatan IbM Kelompok tani padi rakyat, dengan penerapan varietas unggul hibrida baru dan teknik jajar legowo yang telah dilaksanakan dapat disimpulkan sebagai berikut :

1. Budidaya tanaman dengan varietas unggul hibrida baru dan teknik jajar legowo dapat berjalan dengan sebagaimana yang direncanakan.

2. Pertumbuhan tanaman padi hibrida dengan non hibrida tampak lebih subur dan lebih produktif dibanding padi non hibrida.

3. Pertumbuhan tanaman pada baris bagian tepi sistem jajar legowo lebih baik dari tanaman pada sistem tanam biasa.

4. Peningkatan hasil gabah varietas hibrida dibanding non hibrida adalah 20,42\%, peningkatan hasil sistem legowo $2: 1$ dibanding sistem tegel 20x20 adalah 9,29\%, peningkatan hasil sistem legowo 5:1 dibanding sistem tegel 20x20 adalah 6,24\%.

\section{Saran}

Penanaman padi varietas unggul hibrida maupun varietas unggul nasional sebaiknya ditanam dengan system tanam jajar legowo 2:1.

\section{DAFTAR PUSTAKA}

[1] Abdullah, B., Suwarno, B. Kustianto, dan H. Siregar. 2004. Pembentukan galurpadi sawah tipe baru. http://www.indobiogen.or.id. [3 Maret 2014].

[2] Departemen Pertanian, 2008. Sekolah lapang pengelolaan tanaman terpadu (SL-PTT) padi. Panduan Pelaksanaan. Departemen Pertanian.

[3] Badan Litbang Pertanian, 2007. Dukungan Litbangtan untuk peningkatan produksi beras nasional (P2BN).Badan Penelitian dan Pengembangan Pertanian. Jakarta Jakarta

[4] Permana S, 1995. Teknologi usahatani mina padi azolla dengan cara tanam jajar legowo. Mimbar saresehan Sistem Usahatani Berbasis Padi di Jawa Tengah.BPTP Ungaran.

[5] Prajitno KS, R. Mudijisihono, dan B. Abdullah. 2006. Keragaan beberapa genotipe padi menuju perbaikan mutu beras. http://ntb.litbang.deptan.go.id. [3 Maret 2014].

[6] Purwanto S., 2008. Implementasi kebijakan untuk pencapaian P2BN.Prosiding seminar apresiasi hasil penelitian padi menunjang P2BN. Balai Besar Penelitian Tanaman Padi. Sukamandi.

[7] Sembiring H, 2008. Kebijakan penelitian dan rangkuman hasil penelitian $B B$ Padi dalam mendukung peningkatan produksi beras nasional.Prosiding seminar apresiasi hasil penelitian padi menunjang P2BN. Balai Besar Penelitian Tanaman Padi Sukamandi.

[8] Suhargiantono, 2006.Program percepatan peningkatan produktivitas padi di Jawa Tengah.Makalah pada Pertemuan teknis peningkatan kinerja jaringan penyuluhan pertanian.BPTP Jawa Tengah.

[9] Suhendrata T, T. J. Paryono, S. Yunus, Widarto, M D. Pawarti, I. Herianti dan I. Hadisubroto. 2004. Laporan Pengkajian. BPTP Jawa Tengah.

[10] Suhendrata T, E. Kushartanti dan S. Joni Munarso, 2008. Keragaan beberapa padi varietas unggul baru di lahan sawah irigasi Desa Palur, Kecamatan Mojolaban, Kabupaten Sukoharjo.Prosiding seminar apresiasi hasil penelitian padi menunjang P2BN. Balai Besar Penelitian Tanaman Padi. Sukamandi.

[11] Sumiyati. 2007. Uji Daya Hasil Lanjut (UDHL) Galur Harapan Padi Sawah(Oryza sativa L.) Tipe Baru di Kabupaten Bandung. Skripsi. Program Studi Pemuliaan Tanaman dan Teknologi Benih. Fakultas Pertanian,Institut Pertanian Bogor. Bogor. 52 hal.

[12] Widarto dan Yulianto, 2001.Teknologi tanam padi sistem jajar legowo dua baris.Rekomendasi paket teknologi pertanian Propinsi Jawa Tengah. BPTP Jawa Tengah. 